\title{
ARROZ VERMELHO: ECOFISIOLOGIA E ESTRATÉGIAS DE CONTROLE
}

\author{
RED RICE: ECOPHYSIOLOGY AND STRATEGIES OF CONTROL
}

\author{
Dirceu Agostinetto $^{1}$ Nilson Gilberto Fleck ${ }^{2}$ Mauro Antônio Rizzardi ${ }^{1}$; \\ Aldo Merotto Junior ${ }^{3}$ Ribas Antônio Vidal ${ }^{2}$
}

\section{- REVISÃo BIBLIOGRÁFICA -}

RESUMO

A interferência exercida pelo arroz vermelho (Oryza sativa $L$.) sobre o arroz cultivado (O. sativa $L$.) é o principal fator que limita o aumento do potencial de rendimento do cereal no Rio Grande do Sul. Este trabalho de revisão tem por objetivo descrever as características ecofisiológicas do arroz vermelho, bem como discutir estratégias que favoreçam o arroz cultivado na competição pelos recursos do meio ou que limitem seu estabelecimento. Devido às semelhanças morfofisiológicas entre ambos, o controle do arroz vermelho não pode ser realizado através do uso isolado de herbicidas seletivos, requerendo a combinação de diversas ações integradas, as quais envolvem métodos preventivos, culturais, físicos e químicos. A presença de elevada infestação de arroz vermelho torna inviável o cultivo de arroz, especialmente quando a dimensão da lavoura impossibilita o controle manual. Nessa situação, os métodos de controle mais eficazes são: uso de sementes pré-germinadas, preparo antecipado do solo com semeadura direta e emprego da rotação de culturas.

Palavras-chave: Oryza sativa, características, interferência, competição, métodos de controle.

\section{SUMMARY}

Interference caused by red rice (Oryza sativa $L$.) on cultivated rice (O. sativa L.) is the main factor that limits increasing grain yield potential of the cereal in the state of Rio Grande do Sul, Brazil. This literature review has the objective of describing ecophysiological characteristics of red rice, as well as to discuss strategies that favour cultivated rice in the competition process for environmental resources or that limit its establishment. Due to morphophysiological similarities between both, red rice control cannot be accomplished through the use of selective herbicides alone, requiring the combination of several integrated actions, involving preventive, cultural, physical and chemical methods. The presence of a high red rice population makes rice production impracticable, especially when the field extension turns hand weeding impossible. In such a condition, the most effective methods of control have been: the usage of pregerminated seeds, early soil preparation combined with no-till seeding, and adaptation of crop rotation.

Key words: Oryza sativa, characteristics, interference, competition, control methods.

\section{INTRODUÇÃO}

O arroz (Oryza sativa L.) é o principal alimento para a maioria da população mundial, constituindo-se, juntamente com o trigo e o milho, nos alimentos mais produzidos no mundo. A produção desse cereal no Brasil é originária, principalmente, das lavouras irrigadas da Região Sul, as quais respondem por $50 \%$ da produção total (SANINT, 1997). No Rio Grande do Sul, o arroz ocupa área semeada superior a 960 mil hectares, produzindo ao redor de 5 milhões de toneladas ao ano. A produtividade obtida no RS alcançou média de 5,1t.ha ${ }^{-1}$ (IRGA, 1998). No entanto, essa produtividade está aquém da alcançada pelas lavouras que adotam alto

\footnotetext{
${ }^{1}$ Engenheiro Agrônomo, Aluno do Programa de Pós-graduação em Fitotecnia, Faculdade de Agronomia da Universidade Federal do Rio Grande do Sul, (UFRGS)

${ }^{2}$ Engenheiro Agrônomo, PhD., Professor do Departamento de Plantas de Lavoura da Faculdade de Agronomia, UFRGS, CP 776, 91501-970, Porto Alegre-RS. Bolsista do CNPq. Autor para correspondência.

${ }^{3}$ Engenheiro Agrônomo, Mestre, Professor do Departamento de Plantas de Lavoura, Faculdade de Agronomia, UFRGS. Recebido para publicação em 18.1099. Aprovado em 05.07.00
} 
nível tecnológico e do potencial obtido nas áreas experimentais.

Este fato deve-se, principalmente, ao controle insatisfatório das plantas daninhas. Entre as espécies daninhas que infestam as lavouras do Estado, destaca-se o arroz vermelho como aquela que mais limita o potencial de produtividade do arroz (SOUZA \& FISCHER, 1986), o qual está presente na totalidade das regiões cultivadas com arroz irrigado. Além disso, aproximadamente um terço da área encontra-se seriamente comprometida, com destaque para a região da Depressão Central, onde muitas lavouras já foram abandonadas devido à alta infestação de arroz vermelho. Estima-se em $20 \%$ as perdas diretas decorrentes da competição exercida pelo arroz vermelho (SOUZA, 1989). Assim, o Estado do Rio Grande do Sul perde, anualmente, cerca de 1,2 milhões de toneladas, valor equivalente a 360 milhões de dólares. Caso sejam consideradas as perdas indiretas, como elevação do custo de produção, depreciação do valor comercial das áreas de cultivo, depreciação comercial do produto colhido, desgaste do equipamento e geração de empregos, as cifras elevam-se ainda mais (MENEZES, 1996).

Botanicamente, o arroz vermelho (Oryza

sativa L.) pertence a mesma espécie do arroz cultivado. Devido à semelhança entre ambos, o controle através do uso de herbicidas seletivos torna-se difícil, requerendo a combinação de múltiplas ações, como: emprego de sementes isentas de arroz vermelho, mudança no sistema de cultivo, uso da rotação de culturas, manejo adequado da água de irrigação e adoção de técnicas culturais alternativas (FISCHER \& RAMIREZ, 1993).

Esta revisão tem por objetivo descrever as características morfofisiológicas do arroz vermelho, sua interferência no arroz cultivado e discutir estratégias que favoreçam o arroz cultivado na competição pelos recursos do meio.

\section{CARACTERÍSTICAS DO ARROZ VERME- LHO}

A denominação "arroz vermelho" deve-se à coloração avermelhada do pericarpo dos grãos, devido ao acúmulo de tanino (OGAWA, 1992) ou de antocianina (PANTONE \& BEKER, 1991). As opiniões quanto à origem do arroz vermelho são algo divergentes. Uma teoria defende o atrativismo, ou seja, a forma originária das atuais cultivares de arroz possuía pericarpo vermelho. Outra teoria hipotetiza que o arroz com pericarpo vermelho surgiu em uma população de arroz branco, devido à degeneração deste. De qualquer modo, a manifestação da colora- ção vermelha do pericarpo do grão é proveniente de um par de genes (Rd e Rc) com dominância simples (PEDROSO, 1985). Segundo OGAWA (1992), desde o ano 700DC, arroz com pericarpo vermelho era cultivado em quase todas as áreas orizícolas do Japão. Entretanto, por problemas decorrentes do baixo rendimento de grãos e do sabor desagradável, esses tipos de arroz deixaram de ser cultivados na segunda metade do século IXX. Mesmo assim, ainda hoje biótipos de arroz com pericarpo vermelho são cultivados no sul da China e na região sudeste da Ásia (OGAWA, 1992). Segundo esse autor, há dúvida se os atuais biótipos de arroz vermelho são descendentes dos biótipos que foram cultivados no passado ou se sofreram mudanças através de cruzamentos naturais. A freqüência de cruzamentos naturais de arroz vermelho com as cultivares comerciais de arroz varia desde $1 \%$ até $52 \%$, sendo maior quanto mais se assemelham os ciclos das cultivares e dos biótipos de arroz vermelho (LANGEVIN $\boldsymbol{e t}$ al., 1990).

As características predominantes de planta e de semente dos biótipos de arroz vermelho que os distinguem das cultivares de arroz são: ciclo mais longo e plantas de porte mais alto do que as cultivares modernas, colmos finos, folhas de cor verde-claro e decumbentes, alto vigor e alta capacidade de afilhamento com emissão de afilhos ontogenicamente atrasados, pericarpo de cor avermelhada, pálea e lema com variação de cor, pilosidade e aderência da pálea e lema no pericarpo, presença ou não de arista, deiscência precoce das espiguetas e sementes com dormência (DIARRA et al., 1985; NOLDIN et al., 1999).

\section{DINÂMICA DAS SEMENTES DE ARROZ VERMELHO}

As sementes de arroz vermelho podem encontrar-se em quiescência (quando não germinam devido a condições desfavoráveis no ambiente) ou em dormência. Geralmente, as sementes apresentamse dormentes, sendo o grau de dormência variável em função do biótipo. Foi constatado que sementes de arroz vermelho podem permanecer viáveis no solo por até 12 anos (SMITH JUNIOR, 1992). A dormência das sementes de arroz vermelho, associada à persistência das sementes no solo, são formas de dispersão no tempo, que podem ser consideradas como fatores limitantes no estudo da espécie e na adoção de práticas de controle. A produção de afilhos ontogenicamente atrasados e o degrane escalonado são formas de dispersão no tempo que também dificultam as práticas de controle. 
A dormência das sementes pode ser induzida durante seu desenvolvimento, sendo afetada pela luz, temperatura, umidade e pelas condições nutricionais da planta (TAKAHOSHI, 1995). A ocorrência de dormência nos estádios finais de amadurecimento é vantajosa para a planta, pois representa uma barreira à germinação da semente madura ou quase madura, quando ainda se encontra na planta mãe (BRYANT, 1989). A dormência pode ocorrer quando o endosperma e as brácteas atuam como barreira mecânica na elongação, impedindo a saída da radícula, ou interferindo na entrada de água e oxigênio e na saída de $\mathrm{CO}_{2}$, ou devido à presença de inibidores contidos na cobertura seminal que impedem o alongamento da radícula (BEWLEY, 1997). Segundo TAKAHOSHI (1967), a dormência também se deve à imaturidade fisiológica do embrião. Outros trabalhos, no entanto, sugerem, que a dormência em arroz vermelho está ligada à impermeabilidade das estruturas que cobrem as sementes à difusão do oxigênio. Mais especificamente, o mecanismo responsável seria a impermeabilidade ao oxigênio através do complexo glumelas-pericarpo (LARINDE, citado por MARCHEZAN, 1994).

A identificação de ciclos de dormência apresenta importante papel na interpretação do comportamento ecológico da espécie no campo. Além disso, seu conhecimento pode ajudar no desenvolvimento de técnicas visando a acelerar a redução dos bancos de sementes de espécies daninhas.

\section{INTERFERÊNCIA EXERCIDA PELO ARROZ VERMELHO}

A principal forma de interferência entre plantas daninhas e cultivadas é a competição interespecífica. A competição se estabelece quando a intensidade de apreensão de recursos do ambiente pelos competidores suplanta a capacidade do meio em fornecê-los. A competição pode ser definida como sendo a apreensão ou consumo conjunto, por duas ou mais plantas, de recursos essenciais ao seu crescimento e desenvolvimento, os quais estão limitados no ecossistema comum que dividem (PITELLI, 1985). Para que ocorra competição é necessário que haja suficiente sobreposição dos nichos dos indivíduos envolvidos, de forma que eles utilizem simultaneamente os mesmos recursos.

$\mathrm{O}$ arroz vermelho compete com o cultivado especialmente por luz, mas, dependendo das circunstâncias, também por água e nutrientes. Por pertencerem a mesma espécie botânica, as condições edafoclimáticas que favorecem o arroz cultivado geralmente favorecem o arroz vermelho. Para se determinar com exatidão os efeitos da competição do arroz vermelho sobre o cultivado é necessário conhecer-se: densidade do arroz vermelho que causa redução no potencial de rendimento do arroz cultivado (nível de dano ecológico); estádio de desenvolvimento do arroz cultivado em que ocorre interferência do arroz vermelho; identificação do recurso responsável pela competição e características morfológicas possíveis de serem introduzidas no arroz cultivado através do melhoramento genético visando a aumentar sua habilidade competitiva.

\section{Redução no potencial de rendimento do arroz cultivado}

A infestação de arroz vermelho é citada com freqüência como responsável pela redução do potencial de rendimento do arroz cultivado em várias regiões do mundo, inclusive no Rio Grande do Sul. De acordo com SMITH JUNIOR (1988), 20 plantas de arroz vermelho $\mathrm{m}^{-2}$ reduziram em 10, 20, 50 e $68 \%$ o rendimento de grãos da cultivar de arroz Newbonnet cultivada em densidade de 215 plantas $\mathrm{m}^{-2}$, respectivamente com 46, 65, 103 e 120 dias de interferência. Pesquisa realizada por FISCHER \& RAMIREZ (1993) constatou reduções no rendimento de 40 e $60 \%$, respectivamente, para populações de 5 e 20 plantas de arroz vermelho $\mathrm{m}^{-2}$. A presença de plantas de arroz vermelho que formaram $5,55,85$ e 170 panículas $\mathrm{m}^{-2}$ reduziu o rendimento de grãos em 12, 19, 36 e $50 \%$ para a cultivar BRIRGA 409 e em 8, 20, 35 e 49\%, para a cultivar BRIRGA 410, respectivamente (SOUZA \& FISCHER, 1986). Em média, a presença de uma planta de arroz vermelho $\mathrm{m}^{-2}$ reduz em $2,1 \%$ o rendimento de grãos do arroz cultivado (DIARRA et al., 1985; PANTONE \& BAKER, 1991).

Um estudo conduzido durante 4 anos (PANTONE \& BAKER, 1991) comprovou que o arroz vermelho possui maior habilidade competitiva que a cultivar Mars, sendo dominante na comunidade. Os autores observaram que populações de arroz vermelho de 4, 16, 25 e 300 plantas $\mathrm{m}^{-2}$ reduziram o rendimento da cultivar em $20,43,57$ e $91 \%$, respectivamente. A presença de uma única planta de arroz vermelho causou redução no rendimento de cada planta da cultivar equivalente à presença de quatro plantas da própria cultivar, demonstrando assim a maior competitividade do arroz vermelho. Dessa forma, verifica-se que o grau de interferência exercido pelo arroz vermelho varia com o nível de infestação, condições edafoclimáticas, características da cultivar, período de convivência e biótipo encontrado na área. 
Estádios de desenvolvimento em que ocorre interferência e principal recurso responsável

A competição entre arroz vermelho e cultivado ocorre essencialmente pelo recurso luz, e a habilidade competitiva das plantas em utilizá-lo depende da capacidade intrínseca de assimilação de $\mathrm{CO}_{2}$ e sua utilização na fotossíntese para produção de massa seca, com conseqüente aumento da área foliar (BLACK et al., 1969). Acredita-se que a competição do arroz vermelho com o arroz cultivado até 40 dias após a emergência não resulta em redução acentuada em seu rendimento de grãos (FISCHER \& RAMIREZ, 1993). A maior interferência costuma ocorrer nos estádios mais adiantados do ciclo da cultura. Devido às maiores estatura de planta e produção de biomassa, o arroz vermelho intercepta maior quantidade de radiação solar, apresentando, assim, maior atividade fotossintética e, conseqüentemente, maior produção de fotoassimilados.

O sombreamento projetado pelo arroz vermelho diminui a quantidade de luz absorvida pelas folhas do arroz cultivado, provocando alterações morfológicas nas plantas. Quanto à qualidade de luz, o sombreamento altera a relação fitocromo vermelho/fitocromo vermelho extremo que são indicadores do prenúncio da competição. A maior proporção de luz vermelha extrema sobre a luz vermelha provoca formação de folhas alongadas e desenvolvimento de poucos afilhos (ALMEIDA et al., 1998).

\section{Características morfológicas do arroz cultivado que podem aumentar sua habilidade competitiva}

Diversas características morfológicas são propostas visando a melhorar a habilidade competitiva do arroz cultivado em relação ao arroz vermelho. Embora as características sejam de herança quantitativa, governadas por diversos genes e bastante influenciadas pelo ambiente, a população de arroz concentra uma grande variabilidade genética, aumentando desse modo a possibilidade de seleção.

\section{Crescimento inicial}

Esa característica está diretamente ligada ao aproveitamento da radiação disponível no estádio inicial do desenvolvimento da cultura. O crescimento inicial e a concomitante acumulação de matéria seca são dependentes da assimilação de carbono através da fotossíntese e partição de assimilados (CAUSSE et al., 1995). Plântulas com crescimento rápido possuem maior capacidade competitiva devido ao maior porte e área foliar que desenvolvem (ROOD et al., 1990). A maior interceptação de radiação solar pelo arroz ocorre pouco antes da floração, período em que as plantas atingem o nível máximo de área foliar, demonstrando que ocorre desperdício de radiação nos estádios iniciais de desenvolvimento. Nesse sentido, plantas com maior crescimento inicial beneficiam-se da maior captação de radiação, tornando-se mais competitivas.

\section{Afilhamento}

Do ponto de vista competitivo, a emissão de oito a dez afilhos produtivos por planta seria ideal, pois eles propiciariam maior cobertura do solo no período inicial de crescimento. Além disso, preveniriam possíveis falhas de germinação, mantendo o estande de plantas. As cultivares modernas, quando em condições ótimas (radiação, água, nutrientes e espaço físico), apresentam potencial de formar até 25 afilhos (KHUSH, 1995). Devido às elevadas densidades de semeadura normalmente utilizadas, verifica-se a emissão de apenas dois ou três afilhos produtivos, sendo os demais improdutivos. A eliminação dos afilhos improdutivos pode direcionar mais nutrientes à produção de grãos; entretanto, sua contribuição ao rendimento ainda não está devidamente quantificada.

A elevada capacidade de afilhamento da planta de arroz interessa do ponto de vista econômico pela possibilidade de reduzir a quantidade de sementes utilizadas. Por outro lado, estudo demonstra que em comunidades de gramíneas formadas por plantas com características morfológicas semelhantes, ocorre redução no afilhamento bem antes de ocorrer sombreamento mútuo entre plantas (BALLARÉ $\boldsymbol{e t}$ al., 1987). Esses autores propuseram como explicação que a radiação vermelha extrema, refletida pelas folhas, poderia atuar como um sinal precoce da competição que irá ocorrer posteriormente na comunidade. Dessa forma, a elevada capacidade de afilhamento é útil em prevenir falhas na germinação, não podendo ser dispensada a utilização de elevadas densidades de sementes em lavouras que apresentam altos níveis de infestação de plantas daninhas.

\section{Estatura de planta e formação de colmos}

A estatura é o principal ponto de divergência entre o ideotipo de planta proposto para máximo rendimento de grãos e aquele ideal para competição com plantas daninhas. A diminuição da estatura reduz a respiração de manutenção e contribui para a melhoria do balanço fotossíntese/respiração (TANAKA et al., 1966). Além disso, baixa estatura reduz o acamamento e conduz a um maior índice de colheita. Por outro lado, a maior estatura de planta aumenta a habilidade competitiva, pois incrementa a massa seca total e torna a planta mais eficiente na competição por luz. Segundo pes- 
quisa conduzida por MENEZES \& SILVA (1998), o maior ciclo e a maior estatura de planta da cultivar BR-IRGA 410 proporcionam-lhe vantagem em relação à cultivar IRGA 416, em termos de competição com arroz vermelho, reduzindo proporcionalmente mais a massa seca por planta e o rendimento de grãos da infestante.

De outro modo, colmos fortes e apropriada partição de fotoassimilados permitem aumento da fitomassa, sem que isso resulte em características agronômicas negativas como acamamento, sombreamento mútuo, incidência de moléstias e redução no rendimento de grãos (VERGARA, 1988). Não é difícil aumentar a produção de fitomassa quando o arroz é cultivado em ambiente de alta radiação solar, desde que exista suprimento abundante de nitrogênio (AKITA, 1989). Plantas com colmos fortes toleram maiores doses de nitrogênio, resultando em maior taxa de crescimento da cultura.

\section{Folhas}

Em condições de alta luminosidade e elevado índice de área foliar, a luz é mais eficientemente usada em dosséis com folhas eretas (YOSHIDA, 1972), sendo a assimilação de carbono maior quando a folha é exposta à luz em ambos os lados. Uma comunidade de plantas com folhas orientadas verticalmente possibilita maior penetração à luz e maior assimilação de carbono por unidade de área foliar e manutenção de folhas funcionais na base da planta.

A manipulação do tamanho da folha é uma alternativa para aumentar a fixação de $\mathrm{CO}_{2}$ por área de solo. O tamanho de folha também apresenta implicações na distribuição e na qualidade da luz dentro da comunidade e em seus efeitos sobre a modulação do crescimento das plantas (SMITH et al., 1990). Em uma comunidade de plantas, folhas pequenas no estádio inicial de crescimento podem ser fundamentais na determinação do potencial produtivo. Com folhas menores, há melhor qualidade de luz na comunidade, devido à menor absorção de radiação vermelha (ALMEIDA et al., 1998). Por outro lado, ao se buscar maior capacidade competitiva da cultura com o arroz vermelho, o aumento da área foliar devido ao aumento do tamanho da folha, proporcionará sombreamento às plantas de arroz vermelho, o que afetará seu crescimento e afilhamento.

\section{Sistema radicular}

As raízes são relativamente pouco estudadas quando comparadas com o restante da planta. Raízes espessas e profundas proporcionam melhor ancoragem da planta e aumentam a resistência ao acamamento. O crescimento precoce de raízes pode conferir significativa vantagem competitiva em casos onde predominam as interações abaixo do solo (SEIBERT \& PEARCE, 1993). Os nutrientes absorvidos precocemente, no início da estação de crescimento e, em conseqüência, privados de uso por plantas vizinhas, podem ser redistribuídos na planta posteriormente. Dessa forma, quanto mais extenso for o sistema radicular, maior será a capacidade de absorção de nutrientes e, em conseqüência, maiores serão a capacidade competitiva e produtiva da planta.

\section{Duração do ciclo}

A duração ótima do ciclo para se obter máximo rendimento de grãos deve ser de cerca de 120 dias (YOSHIDA, 1972). Ciclo de até 120 dias possibilita colher a cultura antes que o arroz vermelho esteja em fase de maturação, possibilitando retirar da lavoura parte das sementes formadas, diminuindo o banco de sementes. Variações na duração do ciclo refletem basicamente no período de crescimento vegetativo. Cultivares de ciclo menor que 100 dias apresentam menor estatura e conseqüente menor habilidade competitiva. Já cultivares de ciclo tardio apresentam maior estatura e maior capacidade competitiva, porém, são suscetíveis ao acamamento, o que pode inviabilizar a colheita. Desse modo, ciclo de 120 dias permite que a planta utilize mais eficientemente o nitrogênio e a radiação solar, resultando em rápido crescimento, maior capacidade competitiva e conseqüente maior rendimento de grãos.

\section{ALTERNATIVAS PARA MINIMIZAR A INTERFERÊNCIA DO ARROZ VERMELHO}

Vários são os métodos que podem ser utilizados objetivando minimizar a interferência exercida pelo arroz vermelho. Contudo, cabe ressaltar que é necessário a utilização conjunta desses métodos para se conseguir uma lavoura isenta dessa invasora.

\section{Uso de sementes isentas de arroz vermelho}

$\mathrm{O}$ sucesso de qualquer programa de manejo do arroz vermelho inicia com o uso de sementes de arroz livres de sementes de arroz vermelho (SMITH JUNIOR, 1991). O uso de sementes contaminadas é considerado o principal mecanismo de dispersão do arroz vermelho nas lavouras de arroz no Rio Grande do Sul. Entretanto, grande número de produtores ainda utiliza sementes contaminadas com arroz vermelho (IRGA, 1994). Essa prática é oficializada através das normas do Ministério da Agricul- 
tura que regulamentam a comercialização de sementes e mudas, pois ainda é permitida a comercialização de sementes de arroz cultivado, padrão fiscalizada, com até duas sementes de arroz vermelho do biótipo casca clara por amostra de $500 \mathrm{~g}$. Contudo, essa situação já foi pior, pois no início da década de 80 era permitido a presença de até 12 sementes de arroz vermelho por amostra (MENEZES, 1996).

\section{Preparo antecipado do solo com semeadura direta}

Conhecido como cultivo mínimo, esse é o método de semeadura atualmente mais difundido no Rio Grande do Sul. Nesse sistema, o preparo da área a ser cultivada pode ser realizado de duas formas. A primeira consiste em preparar o solo no período de janeiro a abril e estabelecer pastagem durante a estação fria ou manter a área em pousio. A segunda forma consiste em preparar o solo nos meses de inverno, deixando a área em pousio durante o período da primavera, o que propicia o desenvolvimento de vegetação espontânea. Independente da forma de preparo do solo no período que antecede a semeadura, realiza-se dessecação da vegetação existente com herbicidas de ação total (SOUZA, 1989). As principais vantagens desse sistema são o satisfatório controle de arroz vermelho e a redução nos custos da lavoura, devido ao menor número de operações de preparo do solo que são realizadas.

\section{Sementes pré-germinadas}

Trabalhos de pesquisa demonstram ser essa uma estratégia de manejo das mais eficientes no controle de arroz vermelho (AVILA et al., 1997), sendo inferior apenas ao método de transplante de mudas (NOLDIN, 1988). O sistema consiste em efetuar-se o nivelamento prévio da área cultivada e em proceder-se à pré-germinação das sementes antes da semeadura. A elevada eficiência do método na supressão da emergência do arroz vermelho deve-se ao fato da semeadura ser realizada em solo submerso com lâmina de água de 10 a $15 \mathrm{~cm}$. Nesse sistema, a água pode ser manejada de três formas: manutenção da lâmina de água desde a semeadura até a colheita; drenagem da água 2 a 3 dias após a semeadura para se evitar o estiolamento das plântulas de arroz, com a desvantagem de permitir a emergência de arroz vermelho; e, rebaixamento da lâmina de água, mantendo-se o solo saturado e elevando a lâmina de água gradativamente (NOLDIN, 1988).

\section{Transplante de mudas}

O sistema de transplante de mudas ainda é pouco difundido no Rio Grande do Sul, embora possa oferecer elevado controle de arroz vermelho
(NOLDIN, 1988). Atualmente, esse sistema vem sendo utilizado em algumas áreas para produção de sementes, apresentando vantagens, como: menor densidade de semeadura (25 a $\left.30 \mathrm{~kg} \cdot \mathrm{ha}^{-1}\right)$; maior competitividade da cultura com as plantas daninhas (pela melhor eqüidistância entre as plantas) e maior eficiência de controle pela presença de água desde o transplante das mudas; e, facilidade de realização do arranquio das plantas de arroz vermelho devido ao maior espaçamento entrelinhas da cultura $(30 \mathrm{~cm})$. O transplante de mudas, quando realizado manualmente, demanda excessiva mão de obra. Por outro lado, o uso de mecanização, além de também apresentar custo elevado, apresenta pequeno rendimento $\left(\right.$ há.dia $\left.{ }^{-1}\right)$, devido às transplantadeiras existentes no mercado serem de pequeno porte.

\section{Rotação de culturas}

A rotação de culturas é a alternativa mais prática e econômica disponível para redução do banco de sementes de arroz vermelho, podendo ser utilizada em diferentes condições de cultivo. Entretanto, essa prática é pouco implementada, devido, principalmente, à falta de culturas alternativas economicamente viáveis que se adaptem às condições de solo encharcado, elevada precipitação pluvial e deficiente drenagem das várzeas (MENEZES et al., 1994).

A alternância de culturas, aliada ao controle químico seletivo do arroz vermelho durante o cultivo alternativo, tem sido utilizada com sucesso nos Estados Unidos da América (DIARRA et al., 1985). No Rio Grande do Sul, o sistema de rotação comumente empregado é cultivar arroz por 1 ano e manter pastagem nativa por 2 a 3 anos. A rotação de culturas, além de reduzir o banco de sementes de arroz vermelho, otimiza o aproveitamento das máquinas e de mão de obra, diluindo os custos fixos e melhorando as condições físicas e químicas do solo.

\section{Revolvimento do solo durante o pousio}

Nas áreas com grande infestação de arroz vermelho, o pousio (descanso da área) é prática obrigatória, sendo normalmente praticados dois cultivos de arroz a cada 5 anos. A mobilização do solo através de gradagens durante a estação quente no período de pousio favorece a emergência do arroz vermelho, o qual poderá ser controlado com nova gradagem ou utilizado para pastoreio, reduzindo, assim, o banco de sementes. Esse método apresenta a desvantagem de não possibilitar o cultivo de arroz em anos sucessivos. Além disso, nas áreas de maior declividade, o revolvimento freqüente do solo favorece a erosão. Por outro lado, essa forma de manejo não implica custo elevado ao produtor, por não demandar aquisição de novos equipamentos. 
Um cuidado que deve ser tomado é utilizar, no preparo do solo para a semeadura, o mesmo equipamento usado para a mobilização do solo no período de pousio, evitando-se, assim, o revolvimento do solo a maior profundidade. Caso contrário, sementes que se encontravam quiescentes nas camadas mais profundas serão trazidas para a superfície onde germinarão (MARCHEZAN, 1994).

\section{Cultivares e época de semeadura}

$\mathrm{O}$ uso de cultivares de ciclo precoce constitui-se em alternativa para reduzir o potencial de infestação de arroz vermelho nas lavouras. Nessa situação, a colheita do arroz é realizada antes da maturação fisiológica do arroz vermelho (SCHERER, 1987), retirando-se antecipadamente as sementes da lavoura, de modo a propiciar diminuição do reabastecimento de sementes no banco. $\mathrm{O}$ uso de cultivares de ciclo tardio (maior que 135 dias), geralmente mais competitivas em comparação às de ciclo curto (KAVANO et al., 1974), não é recomendável, pois se aumenta o potencial de infestação, visto que praticamente todas as sementes de arroz vermelho sofrerão degrane em período anterior à colheita. Dessa forma, cultivares de ciclo mais curto são ideais para se diminuir os efeitos da interferência do arroz vermelho e prevenir sua persistência nos anos seguintes.

Outro método que visa a diminuir a interferência do arroz vermelho é antecipar a época de semeadura do arroz, buscando-se com isso reduzir a emergência da infestante através do menor revolvimento no solo no período propício à emergência do arroz vermelho. No entanto, o uso isolado e constante dessa prática favorece a seleção de biótipos de arroz vermelho de ciclo mais precoce que o do arroz cultivado.

\section{Controle químico}

Atualmente, não existe possibilidade do emprego seguro de herbicidas seletivos para controle de arroz vermelho em pós-emergência. Trabalhos de pesquisa relatam a utilização de herbicidas em présemeadura com incorporação, aplicados cerca de 25 dias antes da semeadura, ou com incorporação no momento da semeadura e utilização de um antídoto nas sementes (AVILA et al., 1997). Outro método constitui-se na aplicação de herbicidas de ação total, na forma de "barra química", valendo-se da diferença de estatura entre as plantas de arroz vermelho e cultivado. Esse método apresenta a desvantagem de demandar muita mão de obra e de mostrar-se inócuo em prevenir a competição interespecífica, já que só é viável a partir do período reprodutivo.

Outra forma de atuação é através do uso do regulador de crescimento hidrazida maléica, de ação sistêmica e não seletiva que atua como inibidor da divisão celular. Devido a tais características, só pode ser aplicado em cultivares com ciclo mais precoce do que o do arroz vermelho. A época ideal de aplicação é quando as espiguetas de arroz encontrarem-se em estádio de grão pastoso e as do arroz vermelho em estádio anterior a este (ANDRES \& MENEZES, 1997).

A utilização de herbicidas dessecantes de ação total (glyphosate, glufosinate e paraquat), aplicados na fase de maturação fisiológica do arroz cultivado, suprimem a produção de sementes de arroz vermelho e apressam a redução da umidade dos grãos de arroz, o que permite antecipar a colheita. Para que a utilização desse método seja possível, é necessário haver diferença entre os ciclos do arroz cultivado e do vermelho, o que pode ser obtido pelo emprego de cultivares precoces ou super precoces (AGOSTINETTO, 2000).

\section{Outros métodos}

O arranjo das plantas de arroz é uma estratégia que pode ser utilizada para minimizar a competição exercida pelo arroz vermelho, de modo que quanto mais eqüidistantes elas estiverem dispostas, menor será a competição intra-específica e melhor será a cobertura do solo que propiciam, dificultando a emergência do arroz vermelho e a competição por luz (KAVANO et al., 1974). O aumento da densidade de semeadura, associado a menores espaçamentos entrelinhas, é outra estratégia que pode ser utilizada para favorecer a competitividade do arroz em relação ao arroz vermelho. $\mathrm{O}$ aumento na densidade de semeadura do arroz cultivado reduz o número de afilhos por planta e de panículas por área, atribuindo maior capacidade de competição à cultura (MENEZES, 1996).

A adubação da cultura do arroz, quando em competição com arroz vermelho, pode não proporcionar os benefícios esperados. O principal nutriente pelo qual ocorre competição entre plantas daninhas e cultivadas, é o nitrogênio. A aplicação de nitrogênio na semeadura e próximo às linhas aumenta a competitividade do arroz cultivado com o arroz vermelho. Por outro lado, a adubação nitrogenada aplicada no início do desenvolvimento das panículas beneficia mais o arroz vermelho do que o arroz cultivado, em função da sua eficiência na absorção e utilização do nitrogênio, acentuando a diferença de estatura entre os dois tipos de arroz, conseqüentemente aumentando a competição por luz (EBERHARDT, 1998).

A capina manual ou mecânica, embora trabalhosa, é método eficiente no controle de arroz vermelho, especialmente quando associada ao arran- 
quio de plantas e ao uso de sementes de arroz isentas de arroz vermelho. Essa prática propicia aos orizicultores o cultivo continuado, sem necessidade de pousio da área ou uso de outros métodos de controle. $\mathrm{O}$ arranquio poderá ser efetuado a partir da fase de emissão das panículas, ou até antes, se houver pessoal treinado que diferencie as plantas do arroz vermelho das do arroz cultivado (MARCHEZAN, 1994).

A rizipiscicultura é outro sistema que pode propiciar controle de arroz vermelho, a qual se apresenta promissora especialmente em pequenas propriedades quando associada à produção de sementes. Nesse sistema, os peixes revolvem o solo, eliminando a resteva e as sementes das plantas daninhas existentes, possibilitando a semeadura sem necessidade de preparo do solo ou posterior aplicação de herbicida.

O desenvolvimento de plantas geneticamente modificadas, resistentes aos herbicidas de ação total ou a produtos não seletivos, como no caso do grupo químico de herbicidas imidazolinonas, apresenta-se como ferramenta alternativa para o controle seletivo de arroz vermelho na lavoura de arroz (LINSCOMBE et al., 1996). Porém, é necessário considerar as variações de suscetibilidade existentes entre biótipos de arroz vermelho e a possibilidade de ocorrer fluxo de genes da população cultivada resistente para o arroz vermelho suscetível.

\section{CONCLUSÕES}

Em lavouras com elevada infestação de arroz vermelho, o controle pela utilização de um único método torna-se difícil, necessitando o uso conjunto de diversas técnicas de controle, possibilitando, assim, o cultivo continuado na mesma área Para lavouras de médio a grande extensão, onde o controle manual torna-se inviável, os métodos que apresentam melhores resultados são: uso de sementes pré-germinadas; preparo antecipado do solo combinado com semeadura direta e adoção da rotação de culturas.

O sucesso na elaboração de estratégias que visem à diminuição da interferência do arroz vermelho sobre o arroz cultivado depende das características morfofisiológicas das cultivares de arroz, intensidade de infestação e biótipo de arroz vermelho predominante, disponibilidade de máquinas, de investimento e nível de conscientização do orizicultor. O desenvolvimento de um ideotipo de planta mais competitivo com as plantas daninhas, sem prejuízo à capacidade produtiva, reduzirá a necessidade de controle e tornará o setor orizícola mais sustentável.

\section{REFERÊNCIAS BIBLIOGRÁFICAS}

AGOSTINETTO, D. Supressão seletiva da produção de sementes viáveis por arroz vermelho (Oryza sativa $L$.) em condições de lavouras de arroz cultivado. Porto Alegre, 2000. 108p. Dissertação (Mestrado em AgronomiaFitotecnia) - Programa de Pós-graduação em Fitotecnia, Universidade Federal do Rio Grande do Sul, Porto Alegre, 2000.

AKITA, S. Improving yield potential in tropical rice. In INTERNATIONAL RICE RESEARCH INSTITUTE, 1989, Manila. Progress in irrigated rice research... Los Baños : IRRI, 1989. p.41-73. 128p.

ALMEIDA, M. L. de, MUNDSTOCK, C. M., SANGOI, L. Conceito de ideotipo e seu uso no aumento do rendimento potencial de cereais. Ciência Rural, Santa Maria, v.28, n.2, p.325-332, 1998.

ANDRES, A., MENEZES, V.G. Uso de hidrazida maléica no manejo de arroz vermelho em arroz irrigado. In: REUNIÃO DA CULTURA DO ARROZ IRRIGADO, 22, 1997, Balneário Camboriú. Anais... Itajaí : EPAGRI, 1997. p.375-378. 580 p.

AVILA, L.A. de, MARCHEZAN, E., MACHADO, S.L. de O., $\boldsymbol{e}$ al. Sistemas de cultivo de arroz (Oryza sativa L.) irrigado: controle de arroz vermelho (Oryza sativa L.) e de capim arroz (Echinochloa spp.). In: REUNIÃO DA CULTURA DO ARROZ IRRIGADO, 22, 1997, Balneário Camboriú. Anais... Itajaí : EPAGRI, 1997. p.459-461. 580p.

BALLARÉ, C.L., SÁNCHEZ, R.A., SCOPEL, A.L., et al. Early detection of neighbour plants by phytochrome perception of spectral changes in reflected sunlight. Plant Cell Environment, Oxford, v.10, n.2, p.551-557, 1987.

BEWLEY, J.D. Seed germination and dormancy. The Plant Cell, Rockville, v.9, n.7, p.1055-1066, 1997.

BLACK, C.C., CHEN, T.M., BROWN, R.H. Biochemical basis for plant competition. Weeds, Ithaca, v.17, n.3, p.338-344, 1969

BRYANT, J.A. Fisiologia da semente. São Paulo : EPU, 1989. 86p. (Temas de Biologia, v.31).

CAUSSE, M., ROCHER, J., PELLESCHI, S., et al. Sucrose phosphate synthase: an enzyme with heterotic activity correlated with maize growth. Crop Science, Madison, v.35, n.4, p.995-1011, 1995.

DIARRA, A., SMITH, JR.R.J., TALBERT, R.E. Growth and morphological characteristics of red rice (Oryza sativa) biotypes. Weed Science, Champaign, v.33, n.3, p.310-314, 1985.

EBERHARDT, D.S. Manejo da adubação nitrogenada em arroz irrigado e sua relação com a competitividade do arroz vermelho (Oryza sativa L.). Porto Alegre, 1998. 113p. Dissertação (Mestrado em Agronomia-Fitotecnia - Programa de Pós-graduação em Agronomia, Universidade Federal do Rio Grande do Sul, Porto Alegre, 1998.

FISCHER, A.J., RAMIREZ, A. Red rice (Oryza sativa): competition studies for management decisions. International Journal of Pest Management, London, v.39, n.2, p.133-138, 1993. 
IRGA. Divisão de Assistência Técnica e Extensão. Gerência Regional de Pelotas. Campanha da boa semente-Safra 1992/93. Santa Vitória do Palmar: IRGA, 1994. 30p.

IRGA. Divisão de Assistência Técnica e Extensão. Acompanhamento de colheita do arroz irrigado-Safra 1997/98 Porto Alegre : IRGA, 1998. 1p.

KAVANO, K., GONZALES, H., LUCENA, M. Intraespecific competition, competition with weeds, and spacing response in rice. Crop Science, Madison, v.14, n.6, p.841-845, 1974.

KHUSH, G.S. Aumento do potencial genético de rendimento do arroz: perspectivas e métodos. In: CONFERÊNCIA INTERNACIONAL DE ARROZ PARA A AMÉRICA LATINA E O CARIBE, 9., 1994, Goiânia. Arroz na América Latina: perspectivas para o incremento da produção e do potencial produtivo. Goiânia : EMBRAPA-CNPAF-APA, 1995. v.1. p.13-29. 269p. (EMBRPA-CNPAF. Documentos, 60).

LANGEVIN, A.S., CLAY, K., GRACE, J.B. The incidence and effects of hybridization between cultivated rice and its related weed rice (Oryza sativa L.). Evolution, Boulder, v.44, n.4 p.1000-1008, 1990.

LINSCOMBE, S.D., JODARI, F., CHISTOU, P., et al. Potential for use of transgenic rice for the control of Oryza sativa and other rice weeds. In: INTERNATIONAL WEED CONTROL CONGRESS, 2, 1996, Copenhagen. Anais... Copenhagen : CRC, 1996. p.1-6. 327p

MARCHEZAN, E. Arroz vermelho: caracterização, prejuízos e controle. Ciência Rural, Santa Maria, v.24, n.2, p.415-421, 1994.

MENEZES, V.G. Manejo de arroz vermelho através do tipo de arranjo de plantas de arroz irrigado no sistema de cultivo mínimo. Porto Alegre, 1996. 76p. Dissertação (Mestrado em Agronomia-Fitotecnia) - Programa de Pósgraduação em Agronomia, Universidade Federal do Rio Grande do Sul, Porto Alegre, 1996.

MENEZES, V.G., ANDRES, A., SOUZA, P.R. de, et al. Serradela nativa: uma alternativa de inverno para várzea do sul do Brasil. Preços Agrícolas, Piracicaba, v.8, n.91, p.27-29, 1994.

MENEZES, V.G., SILVA, P.R.F. da, Manejo de arroz vermelho através do tipo e arranjo de plantas em arroz irrigado. Planta daninha, Botucatu, v.16, n.1, p.45-57, 1998.

NOLDIN, J.A. Controle de arroz vermelho no sistema de semeadura em solo inundado. Lavoura Arrozeira, Porto Alegre, v.41, n.377, p.11-13, 1988 .

NOLDIN, J.A., CHANDLER, J.M., McCAULEY, G.N. Red rice (Oryza sativa) biology. I. Characterization of red rice ecotypes. Weed Technology, Lawrence, v.13, n.1, p.12-18, 1999.

OGAWA, M. Red rice. Chemistry and organisms, [Japan]. v.30, n.6, p.385-388, 1992.

PANTONE, D.J., BAKER, J.B. Reciprocal yield analysis of red rice (Oryza sativa) competition in cultivated rice. Weed Science, Champaign, v.39, n.1, p.42-47, 1991.
PEDROSO, B.A. Biologia e importância do arroz vermelho. Lavoura Arrozeira, Porto Alegre, v.38, n.359, p.37-38, 1985 .

PITELLI, R.A. Interferência de plantas daninhas em culturas agrícolas. Informe Agropecuário, Belo Horizonte, v.11, n. 129, p.16-27, 1985

ROOD, S.B., BUZZELL, R.I., MAJOR, D.J., et al. Gibberellins and heterosis in maize: quantitative relationships. Crop Science, Madison, v.30, n.2, p.281-286, 1990.

SANINT, L.R. Evolución tecnológica, perspectivas futuras y situación mundial del arroz. In: REUNIÃO DA CULTURA DO ARROZ IRRIGADO, 22, 1997, Balneário Camboriú. Palestras... Itajaí : EPAGRI, 1997. p.7-30. 97p.

SCHERER, C.H. Diagnóstico do arroz vermelho. Lavoura Arrozeira, Porto Alegre, v.40, n.376, p.10-12, 1987.

SEIBERT, A.C., PEARCE, R.B. Growth analysis of weed and crop species with reference to seed weight. Weed Science, Champaign, v.41, n.1, p.52-56, 1993.

SMITH JUNIOR, R.J. Weed thresholds in Southern U. S. rice, Oryza sativa. Weed Technology, Champaign, v.2, n.3, p.232-241, 1988.

SMITH JUNIOR, R.J. Manejo integrado de arroz rojo en arroz. In CONFERENCIA INTERNACIONAL DE ARROZ PARA AMÉRICA LATINA Y EL CARIBE, 1991, Villahermosa. Anais... Cali : CIAT, 1991. p.141-164. 278p.

SMITH JUNIOR, R.J. Red rice control. Agribusiness Worldwide, New York, september/october, p.18-23, 1992.

SMITH, H., CASAL, J.J., JACKSON, G.M. Reflection signals and the perception by phytochrome of the proximity of neighbouring vegetation. Plant, Cell and Environment, Oxford, v.13, n.1, p.73-78, 1990 .

SOUZA, P.R. de. Arroz vermelho: um grande problema. Lavoura Arrozeira, Porto Alegre, v.42, n.387, p.30-31, 1989.

SOUZA, P.R. de, FISCHER, M.M. Arroz vermelho: danos causados à lavoura gaúcha. Lavoura Arrozeira, Porto Alegre, v.39, n.368, p.19-20, 1986.

TAKAHOSHI, N. Dormancy and germination of rice seeds with respects to germination inhibitors. Bulletin Institute of Agricultural Research, Japan, v.18, p.195-212, 1967.

TAKAHOSHI, N. Physiology of dormancy. In: MATSUO, T. KUMAZAWA, K., ISHII, R., et al. Science of the rice plant. Tokyo : Food and Agricultural Policy Research Center, 1995. V.2, p.45-65.

TANAKA. A., KAWANO, K., YAMAGUCHI, J. Photosynthesis, respiration and plant type of the tropical rice plant. Los Banõs : IRRI, 1966. 46p. (IRRI. Technical Bulletin, 7).

VERGARA, B.S. Raising the yield potential of rice. Philippines Technical Journal, Manila, v.13, p.3-9, 1988.

YOSHIDA, S. Physiological aspects of grain yield. Annual Review of Plant Physiology, Palo Alto, v.23, p.437-464, 1972. 